\title{
Assessing Personal Income Tax Amendment Act 2011: Effects on Revenue Generation in Nigeria
}

\author{
Uche Lucy Onyekwelu ${ }^{1} \&$ Uche Boniface Ugwuanyi ${ }^{1}$ \\ ${ }^{1}$ Department of Accountancy, Enugu State University of Science \& Technology, Enugu, Nigeria \\ Correspondence: Uche Lucy Onyekwelu, Department of Accountancy, Enugu State University of Science \& \\ Technology, Enugu, Nigeria. Tel: 234-080-3336-6045. E-mail: anneshalome@yahoo.com
}

Received: May 4, 2014

doi:10.5539/ijef.v6n9p199
Accepted: June 13, 2014

Online Published: August 25, 2014

\begin{abstract}
The study examines the effects of Personal Income Tax Amendment Act 2011 on revenue generation in Nigeria, with a view to exposing the possible challenges and prospects it poses to the Nigerian tax payers. The primary data for this study were sourced using a structured questionnaire while secondary data were sourced through relevant textbooks, academic journals and the internet. The data collected through the questionnaire was analyzed using chi-square statistical method. The study reveals among other things that the increase in the tax rate affected the tax payers revenue generation, and the retroactive nature of our tax laws constitutes a major problem thus: resulting in double taxation during the assessment and collection of taxes. following the findings, the researchers recommends that competent laws should be passed by the government on personal Income tax collection and generation, stiff penalties should be imposed on the tax defaulters and evaders, tax laws should be made less complex, recruitment of qualified personnel to enable them cover fully the scope of work and finally the tax payers should be educated sufficiently on the importance of tax.
\end{abstract}

Keywords: evolution of taxation, types of taxes, income and wealth distribution

\section{Introduction}

\subsection{Background of the Study}

The importance of taxation in the activities of any government cannot be overemphasized. Generally, in Nigeria the law of Personal Income Tax is of tremendous importance as a source of revenue for the government. This importance assumes an accelerated dimension, in the face of the present economic recession in Nigeria (Akintoye, 2013; Asabor, 2012; Oduh, 2012; Angahar \& Sani, 2012.). Personal Income Tax is also a weapon, which could be used to reduce inequality in society, encourage manufacturing industries, by the use of tax incentives, and discourage undesirable industries (Akintoye, 2013; Asabor, 2012; Oduh, 2012; Ariwodola, 2000; Angahar, \& Sani, 2012; Okpe, 1998). But the law on Personal Income Tax in Nigeria has many defects. These contribute a great deal in preventing the law from achieving its desired objectives. The world over, tax is one major source of government revenue (Ariwodola, 2000; Okpe,1998). Tax has been defined in many ways by different authors.

Tax is a compulsory contribution from individuals and business organizations for the purpose of financing government expenditure (Akintoye, 2013; Asabor, 2012; Oduh, 2012; Ariwodola, 2000; Angahar \& Sani, 2012; Okpe, 1998; Asada, 1997). According to him, for government to be able to undertake most of its activities, government raises funds through taxation. To this extent, tax is regarded as a compulsory payment from the private sector to the public sector. It is also a fractional part of income an individual or a body corporate pays to the government to carryout its expenditure. However, not every national government has been able to effectively exploit this great opportunity of revenue generation. This can be attributed to number of reasons including the system of taxation, tax legislation, tax administration and policy issues, over reliance on other sources of revenue such as foreign aid/ grants and so on.

Personal Income Tax (PIT) to an extent has remained unsatisfactory, disappointing and problematic of all the taxes in Nigeria. This is in spite of the fact that tax reform has of recent been a key element in economic reform which the country had undergone. It is therefore; felt that personal Income tax in Nigeria requires radical handling to ensure that a large number of the taxable population does not escape tax. Different Governments have tried to improve the Personal Income tax Act by the various forms of amendment in a bid to making it more effective and goal oriented 
however, events has folded signifying that the Act seems to be facing some teething problems that has hindered it from achieving its goals with an aim of making some submissions that could better reposition the act.

\subsection{Statement of the Problem}

The place of taxation need not be overemphasized. Expectedly, the Personal Income Taxes should be a major source of income to the government. However, PIT has not yielded the much expected results in Nigeria. It is quite regrettable that despite all the series of amendments ensued by many governments on Personal Income Tax Act, it still faces a many limitations especially as is evident in the assessment and collection machinery and hence the need for this study.

\subsection{Objectives of the Study}

The broad objective of this study is to assess the Personal Income Tax Amendment Act of 2011 on its effectiveness on revenue generation in Nigeria, using Enugu State as a case study. This work will specifically:

i. Determine the effects of Personal Income Tax Act Amendment 2011 on tax payers' income.

ii. Determine the effects of PIT Amendment Act, 2011 on relevant tax authorities.

iii. Determine the effect of PIT Amendment Act 2011 on government revenue generation.

\subsection{Research Questions}

The following questions will guide this study:

i. What are the effects of PIT Amendment Act 2011 on tax payer's income?

ii. To what extent has this affected the tax authorities?

iii. What are the effect PIT Amendment Act 2011 affected the revenue generation?

1.5 Research Hypotheses:(Null)

The following hypotheses are formulated to help provide answers to the research questions:

i. Ho: Personal Income Tax Amendment Act, 2011 does not affect the tax payer's revenue.

ii. Ho: Personal Income Tax Amendment Act, 2011 does not affect the assessment and collection of taxes by Board of Internal Revenue.

iii. Ho: The recent P.I.T. Amendment Act, 2011 does not affect the quantum of revenue generated by the government.

\section{Review of Related Literature}

\subsection{Conceptual Framework}

\subsubsection{Taxation in Nigeria: History and Development}

The history of taxation in Nigeria dates back to pre-colonial era. According to Lekan and Sunday (2006) before the colonization of the different entities which were later amalgamated under the name Nigeria, there were different systems of taxation existing in the form of compulsory levies, contributions of goods, money, labour and so on amongst the various kingdoms, groups and tribes of Igala and so on in order to sustain the monarchs.

The present form of taxation in Nigeria could be traced to the establishment of a British Colony in Lagos on August 6, 1891 and subsequent amalgamation of the Southern and Northern protectorates of Nigeria in 1914(Yerokun citizens). In 1904, the Governor-General, Lord Lugard made changes in the tax system, examples of such law include Native Law Ordinance Cap 74 of 1917 applicable to Western Nigeria. This ordinance was the first to introduce Income Tax in Nigeria. In 1918, an amendment was passed that extended the persons of the 1917 ordinance to the Western states. Due to the absence of a recognized central authority in the east, direct taxation was not introduced there until 1927. The re-enactment of the same law in 1929 which saw for the first time imposition of taxes on women, this was however greeted with the Aba Women's Riot in 1929. Another law was that of Non-natives Protectorates Tax Ordinance of 1931. The ordinance was later repealed and incorporated into the Taxation Ordinance No. 4 of 1960 and subsequently re-enacted as the Income Tax Ordinance (I.T.O) of 1943.

The above tax laws were administered on individuals and corporate entities by various tax and revenue officers in the different provinces and regions. In order to promote uniformity in the incidence of taxation throughout the geographical entity called Nigeria, the colonial government in 1958 set up the Raisman Commission. The Commission at the end of its work recommended the introduction of uniform basic income tax principles for application in all regions of Nigeria. This recommendation was accepted by the government which incorporated the same into the 1960 constitution of the Federal Republic of Nigeria that led to the promulgation of the Income 
Tax Management Act (I.T.M.A) of 1961.

The Act saw the setting up a Joint Tax Board (J.T.B) which is charged with the responsibility of determining technical and other issues in which interests of that government might otherwise be in conflict. Each government has sole Jurisdiction to impose Personal Income Tax Act (PITA) 1993 and the Companies Income Tax Act Cap 60 LFN 1990 respectively. As a result of the work of the Tax Laws Review Commission, these laws have been reviewed and updated and are included in the laws of the Federal Republic of Nigeria, 2004. Meanwhile, the current law that governs the administering of Personal Income Tax Act Cap. P8 LFN 2004 imposes Tax on income of individuals and Corporations. Personal Income Tax which is a tax charged on the Income of an individual, Community, family, trusts is regulated by the P.I.T, Act.

The Personal Income Tax (Amendment) Act was assented to by the President of the Federal Republic of Nigeria His excellency goodluck ebele jonathan on the 14th of June 2011. There are a lot of key changes in the Act. Some of the highlights of the Act are:

- Section 2(8) expanded the meaning of "Personal emoluments" to include "benefits in kind." These are benefits received by an employee in the course of employment that does not take the form of money.

- Section 3 (1) (b) was amended by inserting the phrase "temporary or permanent" after the phrase "person to any "in line 5. The section reads; "any salary, wages, fee, allowance or other gain or profit from employment including compensations, bonuses, premiums, benefits or other prerequisites allowed, given or granted by any person to any temporary or permanent employment should make any profit or gain. This will ensure that a large chunk of the taxable population will be brought into tax net. Also introduction of a consolidated tax free allowance of $\$ 200,000$ or 1 percent of gross Income whichever is higher, plus 20 percent of the gross Income and personal relief. Minimum tax in section 37 which was formerly $0.5 \%$ has been reviewed to $1 \%$ of gross income.

Table 1. Below are the revised tax bands

\begin{tabular}{lclc}
\hline Old bands Rates & Old rates & New bands & New \\
\hline First $\$ 30,000$ & $5 \%$ & First $\$ 300,000$ & $7 \%$ \\
Next $\$ 30,000$ & $10 \%$ & Next $\$ 300,000$ & $11 \%$ \\
Next $\$ 50,000$ & $15 \%$ & Next $\$ 500,000$ & $15 \%$ \\
Next $\$ 50,000$ & $20 \%$ & Next $\$ 500,000$ & $19 \%$ \\
Above $\$ 160,000$ & $25 \%$ & Next $\$ 1,600,000$ & $21 \%$ \\
& & Above $\$ 3,200,000$ & $24 \%$ \\
\hline
\end{tabular}

Source: Personal Income Tax (Amendment) Act, Official Gazzet, 2011.

However, the Amended Act changed the basis of computation after deductions of allowances and permissible deductions as stated above. The impact of the change in this section is that lower income earners will pay fewer taxes, and the burden of tax will be bore more by the higher income earners. In the former Act, a person whose income (after permissible deductions) is $\$ 1,100,000$ per annum, would have been paying about $\$ 262,000$ as tax which is about $24 \%$ of the taxable income, while a person earning same amount under the amended law will pay less than $12 \%$ of taxable income which will amount to about $\$ 129,000$. In contrast, a person earning $\$ 10,000,000$ (after permissible deductions) under the old Act will pay about $\$ 2,487,000$ as tax (about $25 \%$ of Taxable Income) and under the new law, such a person will pay about $\$ 2,192,000$. One will notice that under the old Act, high and low income earners paid closely related percentages in taxes regardless of the disparity in the income earned. On the other hand, the new Act takes into cognizance this disparity which reflects in the difference in percentage of taxes paid by each class.

\subsubsection{Types of Taxes}

There are various forms of tax payable in Nigeria. These are broadly classified into:

(a) Direct tax

(b) Indirect tax(Akintoye, 2013; Asabor, 2012; Oduh, 2012; Ariwodola, 2000; Angahar \& Sani, 2012; Okpe, 1998; Asada, 1997).

DIRECT TAX: Direct taxes are levies that are imposed on individuals, companies or corporations. In other words, direct taxes are levies on incomes and properties of those who pay them and bear the burden directly. They are paid 
in the form of personal income tax, capital gains tax and petroleum profit tax (Akintoye, 2013; Asabor, 2012; Oduh, 2012; Ariwodola, 2000; Angahar \& Sani, 2012; Okpe, 1998).

INDIRECT TAX: This is a tax levied on goods and services rendered for which burden is shifted in part or in full to the final consumer who does not even know when he pays or the exact amount he pays. Examples of indirect taxes are entertainment tax, import duties, export duties and value added tax (Akintoye, 2013; Asabor, 2012; Oduh, 2012; Ariwodola, 2000; Angahar \& Sani, 2012; Okpe, 1998).

\subsubsection{Forms of Taxes}

Taxes are classified in the forms:

- Progressive Tax: According to him, a tax is said to be progressive, if its rates increases as the size of income or stock of wealth which is being taxed increases. The burden of a progressive income tax falls more on those with higher incomes.

- Regressive Tax: Regressive tax is the opposite of progressive tax. A tax is said to be regressive if it takes a smaller part of income as income increases. That is, as income increases, the rate of tax decreases.

- Proportional Tax: A tax is proportional where every person pays according to the proportion of income he has, which is when the rich pays more than the poor.

- Ad Valorem Tax: Ad valorem tax is charged according to the value of commodities. (Akintoye, 2013; Asabor, 2012; Oduh, 2012; Ariwodola, 2000; Angahar \& Sani, 2012; Okpe, 1998, Asada, 1997).

\subsubsection{Tax Authorities in Nigeria}

The main bodies recognized by law as tax authorities in Nigeria as stated by the act are:

i. Federal Inland Revenue Services (FIRS): The Federal Inland Revenue, as the name implies, is under the federal government and is responsible for assessment and collection of taxes on the following classes of and groups. They are persons employed in the Nigeria Army, Navy, Air Force, individuals' resident in Abuja (Federal Capital Territory), Companies and officers of the ministry of External Affairs and Nigeria Foreign Service.

ii. State Board of Internal Revenue (SBIR): The State Boards of Internal Revenue are responsible for the assessment and collection of taxes of individuals resident in the state and also imposition of penalties on defaulters.

iii. Joint Tax Board: This body oversees the assessment of the taxes of companies.

2.1.5 Why Are Taxes Imposed?

Ariwodola (2000) and Okpe (1998) identify the following as reasons why taxes are imposed on citizens:

a) To Protect Infant Industries: The government imposes tax on imported goods in the form of custom duties, which is an indirect tax. It is worthy to note that when the imported goods are heavily taxed, the price will become very high or relatively higher than that of home-made goods. This will result in a decrease in the quantity demanded of such goods by the people of Nigeria. Consequently, the goods which are produced within the country will be in high demand because the price will be comparatively less than the price of the imported goods. This encourages the local producers of the goods to step up production.

b) To Reduce Inequality of Income: Direct taxes are used to re-distribute income in a country. Ariwodola (2000) submits that it is made to be progressively high and is collected according to the ability to pay thereby maintaining the principle of equality. The poor or low income groups are taxed according to their income while the high income earners (the rich) are highly taxed.

c) To Generate Revenue for Social Services : Okpe (1998) and Oduh, (2012) submit that when taxes are collected, the money is usually expended for the building of schools, construction of roads, provision of pipe-borne water and the establishment of industries- all geared towards raising the living standards of the citizens.

d) To Check the Consumption of Harmful Commodities: Taxes are used to check the consumption of harmful goods. In effect, some goods are heavily taxed, raising their prices and thus reducing their consumption. This will be true if the demands for such goods are elastic (Ariwodola, 2000; Oduh, 2012; Angahar \& Sani, 2012; Okpe, 1998).

e) To Check Inflation: Taxation can be used to counter inflation. Inflation is a persistent rise in the price of goods and services over time. This is a period when there is too much money in circulation. Inflation could be 
checked by increasing taxes levied and reducing government expenditure. This will in effect reduce the disposal income of the people and thus counter inflation (Ariwodola, 2000; Angahar, \& Sani, 2012; Okpe, 1998).

\subsubsection{Importance of Taxation in Nigeria}

Income tax revenue is one of the major sources of revenue for Nigerian government (Angahar \& Sani, 2012; Okpe, 1998). Its importance cannot be overstated. The Nigerian tax system even though has been employed to achieve various economic objectives at notable periods, has basically been structured as a tool for revenue generation which are used to finance the provision of social amenities to the citizenry by the government (Oduh, 2012). This importance assumes an accelerated dimension, in the face of the present economic recession in Nigeria.

Taxation as an instrument of fiscal policy used by government (Akintoye, 2013; Asabor, 2012; Oduh, 2012; Ariwodola, 2000; Angahar \& Sani, 2012; Okpe, 1998). It can be used to stimulate growth in certain sectors of the economy as well as discourage investment in others. Taxation affects the lives of nearly every member of the society. No major accountancy or financial problem can be satisfactorily solved without taking into consideration the tax effect. Little wonder that the 19th century American Statesman and Philosopher, Benjamin Franklin observed that "in this world nothing is certain but death and taxes."

- The use of taxation as an instrument of economic regulation and control: For the purpose of discouraging certain forms of anti-social behavior in the society. Taxation according to Musgrave and Musgrave (1980) can be extensively used in regulating the consumption pattern resulting in economic stabilization. Anti-social behavior such as drinking of alcohol, smoking and pool betting can be controlled by imposition of higher taxes on production of such goods.

- Income and Wealth Distribution: The use of transfer payments and benefits to these members of the society who are less well-off according to Musgrave and Musgrave (1980) is to promote social equality. Taxation as a mechanism for income and wealth distribution holds that the burden of taxation should be heavier for the rich in the society than for the poor so that that taxes collected are used to pay for social services for the less fortunate (Akintoye, 2013; Oduh, 2012; Angahar \& Sani, 2012).

Conclusively, the essence of taxation is to raise revenue for government expenditure or finance government projects, control consumer demand, encourage investment and savings, fight economic depression, inflation and deflation, guarantee equitable distribution of income and wealth, control the general trend of the national economy, and ensure a proper allocation of national resources (Akintoye, 2013; Oduh, 2012; Ariwodola, 2000; Angahar \& Sani, 2012; Okpe, 1998).

\subsubsection{Attribute/Qualities of a Good Tax System}

Akintoye, (2013); Oduh, (2012); Ariwodola, (2000); Angahar and Sani (2012); Okpe (1998); Asabor ( 2012) submit that a good tax system should possess the following attribute:

(a) Equality: Equality refers to the notion that tax payers should pay according to their ability. This is known as progressive taxation where the tax rate rises as the income rises. This is different from proportional or regressive systems of taxation because a tax payer in the same Income group pays equal tax.

(b) Certainty: The tax laws should be stated in such a way that a tax payer can ascertain with minimum of difficulty what is due to the state from him. Tax rates and methods of calculating the amount payable should be clearly stated. Ambiguity should be avoided where there is certainty, people cannot easily avoid or evade paying tax. The assessment authority must send to the tax payer a notice of assessment showing the rate and the amount to be paid.

(c) Convenience: The time and method of payment of taxes should be convenient for tax payers.

For example, the pay-as-you-earn (PAYE) method of tax collection is convenient because the tax is deducted by the employer before the employee receives his or her pay.

(d) Flexibility: The tax system should be flexible. It should be easy to change or amend when conditions and situations change. The tax system should be adaptable enough so as to raise money for the government urgently if the need arises. It must not be rigid.

(e) Neutrality: A good tax system interferes as little as possible with the supply and demand of goods and services. It should not affect people's willingness to work, save or invest.

(f) Economy: A good tax system is one that is economical to run. The cost of tax collection should be small compared with the total tax revenue from a particular tax. 


\subsubsection{Challenges of Personal Income Tax Generation}

There are many problems encountered with the generation of personal Income tax revenue. Therefore, there is still a lot of dissatisfaction in the country over collection and assessment of personal Income tax. The assessment and collection of personal Income tax from taxable individuals have been difficult Nigeria (Asada, 1997; Akintoye, 2013; Oduh, 2012; Ariwodola, 2000; Angahar \& Sani, 2012; Okpe, 1998).

In Nigeria, it is safe to say that personal Income tax is mostly paid by civil servants. This is because the taxes are deducted before the employees receive their pay (Asada,1997; Akintoye, 2013; Oduh, 2012; Ariwodola, 2000; Angahar \& Sani, 2012; Okpe, 1998). Asada, 1997. In private sectors, most employers do not bother with P.A.Y.E deductions. Those that do make deductions do not remit said deductions to the state. Majority of the self employed citizens mostly do not pay income tax. Due to this, a lot of money is lost; money that could have been gainfully used to improve the lot of the populace.

Lack of adequate fraud control provision in our tax laws is another problem encountered in personal income tax generation. Experience has shown that our tax collections are usually susceptible for financial inducement and therefore help tax payers to evade tax. If the tax collectors do collect these taxes, they fail to remit the sums to the state (Asada,1997; Angahar \& Sani, 2012; Okpe, 1998).

Finally, another problem is the shortage of staff for tax collection. For tax collection to be effective and efficient there must be adequate staff. However, there is an acute shortage of qualified and trained personnel in the tax offices. This leads to contraction in tax collection efforts and as a consequence, tax collections are in arrears.

\subsubsection{Assessing Personal Income Tax Amendment Act, 2011: Challenges and Limitations}

There are a lot of problems associated with the administration of personal Income tax. The senior tax administration analyst with the International Monetary Fund (IMF), Peter Griffith as cited in (Asada,1997; Angahar \& Sani, 2012) identified three principle factors that cause great fluctuation in tax revenue. These he described as exogenous; such as changes in the substance of the law, changes in the base to which the tax applies, and changes in the quality and efficient of the administration.

- Changes in the base to which the tax applies is illustrated by the rise and fall of revenue from taxes from year to year on export commodities due to fluctuations in prices in the international market.

- Changes in the substance of the law is amply illustrated by the erratic nature of our taxation laws whereby say revenue is increased through raising the rate of tax or is lost through increasing the exemptions from income tax. This s illustrated in the 1995 budget which increased personal allowances from $\$ 1000$ plus $12 \frac{1}{2} \%$ of earned income to 2000 plus $15 \%$ of earned income. Naturally, tax revenue will reduce.

- Changes in the quality and efficiency of tax laws, lack of trained personnel, lack of a database of taxable persons, lack of adequate penalties for tax evaders, these are just a few constraints that hinder the quality and efficiency of tax administration.

- Administrative challenge: Experience has shown that the institutional Capacity to administer taxes effectively is woefully lacking in this country. Procedures, reinforced by third party audits, appear to ensure that taxes are paid and received albeit with potentially serious and costly internal lags. However, Nigeria lacks capacity to assess the reasonableness of the returns submitted by tax payers, including costs and staffing, skills, pay scale and other funding.

- Compliance challenges: A recurring problem with PIT is the non-compliance of employers to register their employees and to remit such taxes to relevant authorities. To address this, in 2011 the government amended the 2004 PIT Act to make non-compliant employers liable to penalties.

- Absence of Competent tax administrators due to incompetence and absence of honest administrators, the problem of tax avoidance and evasion has reached an alarming proportion. The problem with Income taxation in Nigeria is the administration of the tax system bordering on the tax collection, assessment and widespread corruption.

- Ambiguity of tax laws is a major problem of personal Income tax Act in Nigeria. He stated that the state tax laws and the federal Income management Act have been so subjected to series of piecemeal amendments that it is difficult even for the personal Income tax officials to determine the structure of personal Income tax and its assessment and there is no literature in the tax laws which will help for easy understanding of the laws.

- Furthermore, he highlighted that poor legal structure impairs the objectives of personal income tax. He recommended that the personal Income tax laws of the federal government should be verified as soon as possible. A lot of loopholes abounds in the P.I.T Laws. 
- Finally, the problem of improper orientation of tax payers as to the need and purpose of tax. Most tax payers see taxes as a burden since the perception is that they derive no benefit from paying tax. Such group of individuals should be properly enlightened. Revenue authority should embark on aggressive public enlightenment and education of tax payers on the various taxes.

\subsubsection{Effects of Personal Income Tax (Amendment) Act 2011 on Revenue Generation in Nigeria}

The need to improve the administration of our tax system cannot be overemphasized. Only an efficiently managed tax system is capable of maximizing tax revenue necessary for development. P.I.T.A 2011 has contributed immensely on revenue generation in Nigeria through so many ways. Increase in the rate of minimum tax in section 37 which was formerly $0.5 \%$ has been reviewed and increased to $1 \%$ minimum tax. As a result of this increase, a higher percentage of income tax revenue will be realized thereby increasing revenue accruing to the state. (Asabor, 2012; Asada, 1997; Akintoye, 2013; Oduh, 2012).

Penalties in the Act were also reviewed; such reviews include the penalty for a person engaged in banking services who fails to give the necessary information, documents or books to the relevant tax authority (section 47 and 19 of the Act). Penalty for failing to keep the proper books of account (section 96) have been reviewed from $\$ 5000$ for a corporate body and $\$ 500$ for an individual to $\$ 500,000$ and $\$ 50,000$ respectively. This enhances the increase in revenue generation in Nigeria economy.

Most tax exempt are no longer tax exempt but they are all taxable such as the official emoluments of the President, Vice President of Nigeria, Governor and Deputy Governor of each state in Nigeria. This implies that the income of these officials (including allowances and benefits in kind) is now fully taxable and this will help to increase the revenue generation in Nigeria. In section 3 (1) The amendment clearly captures all employees within the ambit of the law, regardless of whatever name such an employee is so called. Clearly, even a paid intern will be captured by this provision and consequently his income will become taxable and it will amount to great increase in the revenue generation (Asada, 1997; Akintoye, 2013; Oduh, 2012; Ariwodola, 2000; Angahar \& Sani, 2012; Okpe, 1998).

\subsubsection{Effects of Personal Income Tax (Amendment) Act 2011 on Tax Payers}

According to Asabor (2012): The Nigerian tax system has undergone significant changes in recent times. Tax laws are being reviewed with the aim of repealing obsolete provisions and simplifying the relevant ones. Based on the Amendments, a number of challenges will arise from applying the new changes and this will affect the tax payers greatly. Applying the new changes in retrospect including re-computation of Pay-as-You-Earn (PAYE) tax liabilities for 2011 for all staff.

Under the old PITA, interest may be imposed on tax defaults but there was no prescription on how the interest should be applied. Historically, tax authorities apply the interest at a flat rate on a one-off basis. But the new Amendments now explicitly require interest to be calculated on an annual basis. This means simple interest method whereby interest on tax due for a period is multiplied by the number of years outstanding. Where the period contains less than a whole year, then the interest must be prorated on a monthly or daily basis from the date the tax becomes due until it is paid.

Asabor (2012) defines Gross emolument (or income) to include benefits in kind, gratuities, superannuation and any other incomes derived solely by reason of employment. Benefit- in-kind is now specifically included in gross emolument and by implication, taxable income with temporary staff now specifically liable to tax which includes casual workers, and other contract staff. Although the taxable income bands have been increased and the top tax rate reduced marginally from $25 \%$ to $24 \%$, the minimum tax rate has also been increased from $0.5 \%$ to $1 \%$ of gross income. This means about $100 \%$ increases in tax for the poorest of the poor.

However, conditions for exemption from personal income tax for any employment wholly or partly performed in Nigeria are now modified to require evidence that such individuals are liable to tax in another country under the provisions of a double tax treaty. And this might result in double taxation. This is especially so considering that all the conditions are conjunctive and inseparable. Thus, regardless of the fact that the person may be in a country where there is "avoidance of double taxation treaty", such a person will still be taxable if he falls short of any of the stipulated conditions set out in the Act.

\section{Research Methodology}

\subsection{Research Design}

The area studied is important to a growing economy; it deals with the entire economy especially the taxation sector, finding out the effects of personal Income tax Amendment Act 2011 on revenue generation in Nigeria. The research design of this project is the survey/descriptive design. 


\subsection{Sources of Data}

Data for this study was mainly primary data. Primary data refers to first hand material collected by the researcher which aims at making the work of the researcher appear as original as possible Udeze (2005) and Uzoagulu (1997). This includes questionnaires and personal interviews. Each questionnaire has twenty structured questions. These questionnaires were administered and used to elicit responses from respondent for analysis.

\subsection{Population and Sample Size Determination}

This population of this study is Nigeria Tax Payers and tax authorities. Since this population would be near impossible to study, the researcher has selected Enugu State Board of Internal Revenue and Tax payers in Enugu State. The researcher judgmentally chose eighty people as sample size. However, the respondents are expected to comprise of $48(60 \%)$ staff and $32(40 \%)$ taxpayers.

\subsection{Validity of Instrument}

The questionnaire was sent for both content and structural revalidation to experts in the field. The researcher had effected and included all their observations and input before the instrument administered Udeze (2005) and Uzoagulu (1997).

\subsection{Tools for Analysis}

The method of data analysis chosen for this study is the chi-square $\left(\lambda^{2}\right)$ test. According to Sunny Croach, Chi-square is statistically significant tests which measures whether difference in cross-tabulation of data are statistically significant. Chi-square test is also a measure of association between two variables when a researcher wishes to test the hypothesis that two distributions come from the same population. Thus:

where:

$$
\lambda^{2}=\frac{\sum(f o-f e)^{2}}{f e}
$$

Fo = Observed frequency;

$\mathrm{Fe}=$ Expected frequency;

$\sum=$ Summation Sign.

The frequency observed is the number of responses for each category. The frequency expected is the theoretical or chance frequency which must be calculated with the formula. The expected frequency is determined with the formula.

Where:

$$
\frac{\operatorname{Rix} C i}{N}
$$

$\mathrm{Ri}=$ Row total;

$\mathrm{Ci}=$ Column total;

$\mathrm{N}=$ Grand total.

If the values of the observed frequency differ greatly from the expected frequency, the chi-square will be large. The degree of freedom (df) is another important feature of chi-square distribution. It is computed using the formula: $\mathrm{df}=(\mathrm{R}-1)(\mathrm{C}-1)$.

where: $\mathrm{df}=$ Degree of freedom; $\mathrm{R}=$ The number of rows; $\mathrm{C}=$ The number of column.

The decision rule is that if the computed value of chi-square is greater than the critical value, the null hypothesis will be rejected and in the alternative hypothesis will be accepted.

However, if the reverse occurs, the null hypothesis will be accepted.

\section{Presentation and Analysis of Data}

\subsection{Data Presentation}

The data collected using the questionnaire are below presented and analysed thus: 
Table 1. Return of questionnaires

\begin{tabular}{lll}
\hline Description & Frequency & Percentage (\%) \\
\hline Total Distributed & 80 & 100 \\
Total Returned & 50 & 62.5 \\
Total no withheld & 30 & 37.5 \\
\hline
\end{tabular}

Source: Field Survey, 2014

Table 1 show that out a total of 80 eighty questionnaires were administered while 50 Fifty were returned representing a $62.53 \%$ return rate and the responses elicited from therein were used for analysis.

Table 2. Age distribution of respondents

\begin{tabular}{lll}
\hline Responses & Frequency & Percentage (\%) \\
\hline $26-30$ & 5 & 10 \\
$31-35$ & 10 & 20 \\
36 and above & 35 & 70 \\
Total & $\mathbf{5 0}$ & $\mathbf{1 0 0}$ \\
\hline
\end{tabular}

Source: Field Survey, 2014

Table 2 shows that 5 respondents representing 10\% were between ages 26-30, while 10 respondents representing $20 \%$ were between $31-35$ while 35 respondents representing $70 \%$ were of the age range of 36 and above.

Analyses of response to question 4.

Table 3. PIT amendment act 2011 effect on revenue generation

\begin{tabular}{lll}
\hline Responses & Frequency & Percentage $(\%)$ \\
\hline Yes & 50 & 100 \\
No & 0 & 0 \\
Total & 50 & 100 \\
\hline
\end{tabular}

Source: Field Survey, 2014

Table 3 shows that 50 respondent (100\%) admitted that the Amendment Act 2011 brought a positive reform in revenue generation in Nigeria.

Table 4 analyses of response to question 6 .

Table 4. Does the retrospective/retroactive nature of tax laws affects the tax payers revenue?

\begin{tabular}{lll}
\hline Responses & Frequency & Percentage (\%) \\
\hline Yes & 50 & 100 \\
No & 0 & 0 \\
Total & 50 & 100 \\
\hline
\end{tabular}

Source: Field Survey, 2014

This table presented an accurate analysis that none responded "No" while 50 respondents representing $100 \%$ responded "Yes".

Analysis response to question 7. 
Table 5. How would you rate the effectiveness and efficiency of personal income tax amendment act 2011, in BIR Enugu?

\begin{tabular}{lll}
\hline Responses & Frequency & Percentage (\%) \\
\hline Poor & 5 & 10 \\
Very Poor & 0 & 0 \\
Good & 30 & 60 \\
Very good & 10 & 20 \\
Excellent & 5 & 10 \\
Total & 50 & 100 \\
\hline
\end{tabular}

Source: Field Survey, 2014

It is observed that from the above table, 5 respondents representing $10 \%$ responded poor while 30 respondents representing $60 \%$ identified good and 10 respondents representing 20\% identified very good and 5 respondents representing $10 \%$ marked excellent respectively while very poor is nil.

Analyses of response to question 8 .

Table 6. How would you rate the inflow of revenue after the 2011 PIT amendment act in Enugu?

\begin{tabular}{lll}
\hline Responses & Frequency & Percentage (\%) \\
\hline High & 33 & 66 \\
Very high & 17 & 34 \\
Low & 0 & 0 \\
Very low & 0 & 0 \\
Total & 50 & 100 \\
\hline
\end{tabular}

Source: Field Survey, 2014

The result shows that 33 respondents representing 66\% responded high and 17 respondents representing $34 \%$ responded very high respectively while others are nil.

Responses to question 9.

Table 7. Does the PIT amendment act 2011 affect the assessment and collection of taxes?

\begin{tabular}{lll}
\hline Responses & Frequency & Percentage (\%) \\
Yes & 30 & 60 \\
No & 15 & 30 \\
Undecided & 5 & 10 \\
Total & 50 & 100 \\
\hline
\end{tabular}

Source: Field Survey, 2014

The above table shows that 30 respondents' represents 60\% agreed that PIT Amendment Act 2011 affected the assessment and collection of taxes. 15 respondents representing 30\% do not agree while 5 respondents representing $10 \%$ are undecided.

Response to question 10.

Table 8. Does the recent increase in tax rate of PITA 2011 affect the tax payers?

\begin{tabular}{lll}
\hline Responses & Frequency & Percentage (\%) \\
\hline Yes & 50 & 100 \\
No & 0 & 0 \\
Total & 50 & 100 \\
\hline
\end{tabular}

Source: Field Survey, 2013. 
The above table 8 shows that 50 respondents representing $100 \%$ agreed that the recent increase in tax affected the tax payers.

Question 11.

Table 9. Do you consider lack of a comprehensive database of taxable persons a factor that could prevent the Board from carrying out its duties?

\begin{tabular}{lll}
\hline Responses & Frequency & Percentage (\%) \\
\hline Yes & 40 & 80 \\
No & 8 & 16 \\
Undecided & 2 & 4 \\
Total & 50 & 100 \\
\hline
\end{tabular}

Source: Field Survey, 2013.

The table above shows that 40 respondents representing $80 \%$ agreed that lack of comprehensive database of taxable persons is a factor that could prevent the Board from carrying out its duties. 8 respondents representing $16 \%$ disagreed that it is not a problem while 2 respondents representing $4 \%$ are undecided.

Question 12.

Table 10. Does the 2011 PIT amendment act affect the tax payer's revenue generation?

\begin{tabular}{lll}
\hline Responses & Frequency & Percentage (\%) \\
\hline High & 28 & 56 \\
Very high & 2 & 4 \\
Low & 5 & 10 \\
Very low & 0 & 0 \\
Moderate & 15 & 30 \\
Total & 50 & 100 \\
\hline
\end{tabular}

Source: Field Survey, 2013.

Table shows that 28 respondents representing 56\% responded high, while 2 respondents representing 4\% responded very high. 5 respondents representing 10\% responded low and 15 respondents representing 30\% responded moderate respectively while very low was nil.

\subsection{Test of Hypotheses}

By hypothesis, we mean the device by which the researcher used in testing the assertions made in the research work.

For the purpose of this research work, the researcher had employed chi-square $\left(\mathrm{X}^{2}\right)$ approach to test the entire hypotheses. The testing involves the formation of two kinds of hypothesis for each hypothesis to be tested.

(a) Null hypothesis $\left(\mathrm{H}_{0}\right)$;

(b) Alternative hypothesis $\left(\mathrm{H}_{1}\right)$.

DECISION CRITERIA: After the calculation, if the computed value of Chi-square $\left(\mathrm{X}^{2}\right)$ is less than the critical value, then the null hypothesis is accepted. But if the computed value is greater than the critical value, then the alternative hypothesis is accepted. The Chi-square $\left(\mathrm{X}^{2}\right)$ test is used at $95 \%$ level of significance of tolerable error and also the number of degree of freedom in the table is determined, Udeze (2005) and Uzoagulu, (1997).

\subsubsection{Hypothesis One}

$\mathrm{H}_{0}$ : Personal Income Tax Amendment Act 2011 does not affect the tax payer's revenue.

$\mathrm{H}_{\mathrm{i}}$ : Personal Income Tax Amendment Act 2011 affects the tax payer's revenue. 
Table 11. Computation of $\mathrm{X}^{2}$ table value using Table 10

\begin{tabular}{lllllc}
\hline Responses & Oi & $\mathbf{E i}$ & $\mathbf{O i - E i}$ & $(\mathbf{O i}-\mathbf{E i})^{2}$ & $\frac{(\mathbf{O i}-\mathbf{E i})^{2}}{\mathbf{E i}}$ \\
\hline High & 28 & 10 & 18 & 324 & 32.4 \\
Very high & 2 & 10 & -8 & 64 & 6.4 \\
Low & 5 & 10 & -5 & 25 & 2.5 \\
Very low & 0 & 10 & -10 & 100 & 10 \\
Moderate & 15 & 10 & 5 & 25 & 2.5 \\
Total & 50 & 50 & & 538 & 93.8 \\
\hline
\end{tabular}

$\mathrm{Ei}={ }^{50} / 5=10$;

$$
\text { Expected value (ei) }=\frac{\text { Sum of frequency }}{\text { No. of elements }}
$$

$\mathrm{X}=0.05 \rightarrow$ level of significance;

Table value of $\mathrm{X}^{2}=9.488$;

Calculated value of $X^{2}=93.8$.

Decision: Given that the calculated value is greater than the table value that is $93.8>9.488$, the null hypothesis is rejected.

\subsubsection{Hypothesis Two}

Ho: Personal Income Tax Amendment Act 2011 does not affect the assessment and collection of taxes by BIR.

Hi: Personal Income Tax Amendment Act 2011 affects the assessment and collection of taxes by BIR.

Table 12. Computation of $\mathrm{X}^{2}$ table value using Table 11

\begin{tabular}{lllllc}
\hline Responses & $\mathbf{O i}$ & $\mathbf{E i}$ & $\mathbf{O i - E i}$ & $(\mathbf{O i}-\mathbf{E i})^{2}$ & $\frac{(\mathbf{O i}-\mathbf{E i})^{2}}{\mathbf{E i}}$ \\
\hline Yes & 30 & 16.67 & 13.33 & 177.6889 & 10.659 \\
No & 15 & 16.67 & -1.67 & 2.7889 & 0.167 \\
Undecided & 5 & 16.67 & -11.67 & 136.1889 & 8.169 \\
Total & 50 & 50 & & 316.766 & 18.99 \\
\hline
\end{tabular}

$$
\text { Expected value }(\text { ei })=\frac{\text { Sum of frequency }}{\text { No. of elements }}
$$

that is $=50 / 3=16.67$;

Table value of $\mathrm{X}^{2}=5.991$;

Calculated value $\mathrm{X}^{2}=18.99$.

Decision Rule : $X^{2}$ calculated is greater than $X^{2}$ critical.

Therefore, the null hypothesis is rejected and the alternative hypothesis accepted.

4.2.3 Hypothesis Three

Ho: The recent P.I.T Amendment Act 2011 does not affect the structure and willingness of tax payers.

Hi: The recent P.I.T Amendment Act 2011 affects the structure and willingness of tax payer.

Table 13. Computation of $\mathrm{X}^{2}$ table value using Table 8

\begin{tabular}{lllllc}
\hline Responses & $\mathbf{O i}$ & $\mathbf{E i}$ & $\mathbf{O i - E i}$ & $(\mathbf{O i}-\mathbf{E i})^{2}$ & $\frac{(\mathbf{O i}-\mathbf{E i})^{2}}{\mathbf{E i}}$ \\
\hline Poor & 5 & 10 & -5 & 25 & 2.5 \\
Very poor & 0 & 10 & -10 & 100 & 10 \\
Good & 30 & 10 & 20 & 400 & 40 \\
Very good & 10 & 10 & 0 & 0 & 0 \\
\hline
\end{tabular}




\begin{tabular}{llllll}
\hline Excellent & 5 & 10 & -5 & 25 & 25 \\
Total & 50 & 50 & & 550 & 55 \\
\hline
\end{tabular}

$\mathrm{ei}={ }^{50} / 5=10$;

$$
\text { Expected value }(\text { ei })=\frac{\text { Sum of frequency }}{\text { No. of elements }}
$$

Table value of $\mathrm{x}^{2}=9.488$;

Calculated value $\mathrm{x}^{2}=55$.

Decision: Reject null hypothesis since $55>9.488$.

Therefore the 2011 PIT Amendment Act affected the structure and the willingness of tax payers.

\section{Summary of Findings, Conclusion and Recommendations}

\subsection{Summary of Findings}

The findings made from the study reveals that Personal Income Tax Act 2011 affected the revenue generation in Enugu State. However, the foregoing discussion has clearly highlighted the various effects/implications associated with the Act. Some of the major findings of this work are:

- $\quad$ PIT Amendment Act 2011 affected the tax payer's revenue generation due to the increase in the tax rate which constituted a major change in the computation of tax table.

- The retroactive nature of tax laws affects the willingness of tax payers.

- Lack of competent laws has been found to be a serious reason that affected the generation of revenue by the Board of Internal Revenue while carrying out its duties.

- Dearth of comprehensive database of taxable persons is a challenge that needs to be overcome.

- The assessment and collection of taxes and administration is a source of great concern to the Board and that lack of literature in the tax laws contributed on the effects of revenue generation during the assessment and implementation of such tax laws.

- The corrupt tendencies of some tax collectors has reaped the government of the much needed tax revenues..

\subsection{Conclusion}

The study was on the implications of 2011 PIT amendment on revenue generation in Nigeria using Enugu State as a case study. The study has reviewed the processes that characterized the Personal Income Tax before the Amendment of 2011. The responses elicited shows that the Amendment has some positive effect on the system but the system is still grappling with some challenges ranging from poor awareness rate of tax payers concerning the amendment and some poor attitude of tax collectors which has not constituted a cloak in the wheels of the Amendments from achieving the set goals of beefing up government revenues generated through tax.

\subsection{Commendations}

Following from the findings of this study the following recommendations are made:

- Reductions in the direct tax rates and increases in the indirect tax rates especially on luxury items will increase the amounts collected in taxation in Nigeria.

- Government should embark upon other means of publicity such as radio messages, television advertisement, post bills as well as the use of town criers to inform tax payers of changes in tax legislation and need for compliance.

- The government should pass into law amendments to our tax laws that will reflect existing times and the economic plight of the nation and laws should be easy to understand.

- Tax payer's information and history should be computerized and this will facilitate effective monitoring and coordination of tax and Income data.

- The tax authorities should properly review and evaluate the assessment and collection procedures so as to encourage compliance by the tax payers. The usual practice of reprinting parts of the tax laws and sending same to the tax payers expecting that they would understand is not encouraging since these laws are written in legal jargons or terms that are not easily understood. Moreover, tax forms should be made less complex. Vast improvement can be made by improving the design of the forms. 
- Qualified personnel with the right attitude should be recruited, trainned and retrained to man the revenue boards.

- $\quad$ Revenue Personnel generally trained and restrained to cope with the demands of the job. Staff should also be motivated through good salary package to insulate them from fraud and other corrupt practices. In-service training should also be instituted, the staff should be conversant with applicable tax laws and this is only possible with the training. Cash incentives should be given for best performance. This will increase their effectiveness as well as reduce the need for corruption.

- Deliberate effort should be made to educate tax payers on the need to pay taxes while the government should embark on aggressive infrastructural development to justify taxes received.

\subsection{Suggestion for Further Studies}

The researchers are suggesting that further studies be carried out in the following areas:

$>\quad$ Tax Resources Management Strategies in Developing Economies: Implications for Economic Derivatives like GDP, Unemployment rate, Literacy rate and Morbidity rate.

$>$ Making Tax Education Count in Tax Administration in Developing Economies.

$>$ Taxation Disenchantment: How far has it impacted on standard of living in developing economies.

\section{References}

Akintoye, I. R. (2013). The effect of tax Compliance on Economic Growth and Development in Nigeria. Retrieved from http://www.bjournal.co.uk/payers/BJASS-11-2/BJASS 11-02

Angahar, A. P., \& Sani, I. A. (2012). Personal Income tax Administration in Nigeria: Challenges and Prospects for increased revenue generation. Journal of Economic Research, 1(1-11). http://globejournal.org/wp-content/updloads/2012/09/vol1-1-1-11-AAccessed 3/14/2013

Ariwodola, J. A. (2000). Personal Taxation in Nigeria (4th ed.). Lagos: JAA Nigeria Ltd.

Asabor, M. (2012). Personal Income Tax Amendment Act and its effects on Tax payers. http://www.tribune.com.ng/Index.php/taxation/39566-PersonalIncomeaccessed 7.57am 14/3/2013

Asada, D. (1997). The Administration of Personal Income Tax in Nigeria: Some Problem Areas Matches Publishing Ltd.

Oduh, M. (2012). Revenue Implication of Nigeria Tax System, Lagos. Journal of Economic and Sustainable Development, 3(8)

Ogagavworia, M. (2012). Personal Income Tax (Amendment) Act 2011.

Okpe, I. I. (1998). Personal Income tax in Nigeria. Enugu: New Generation Books.

Udeze, J. O. (2005). Business Research Methodology Enugu. Chiezugo Ventures printing and publishing.

Uzoagulu, A. (1998). Practical Guide to writing research projects reports in tertiary institutions. Enugu: John Jacobs Classic Publishers Ltd.

\section{Copyrights}

Copyright for this article is retained by the author(s), with first publication rights granted to the journal.

This is an open-access article distributed under the terms and conditions of the Creative Commons Attribution license (http://creativecommons.org/licenses/by/3.0/). 